\title{
The Relationship Between Energy Import and Defence Expenditures in the Context of Energy Supply Security: The Case of Turkey
}

\author{
Assoc. Prof. Dr. Haluk YERGIN, Asst. Prof. Dr. Mustafa TORUSDAG \\ 1. Van Yüzüncü Y1l University, Faculty of Economics and Administrative Sciences, \\ halukyergin@yyu.edu.tr, Orcid Id: 0000-0002-8168-9115. \\ 2. Van Yüzüncü Y1l University, Faculty of Economics and Administrative Sciences, Department of \\ Economics, mustafatorusdag@yyu.edu.tr, Orcid Id: 0000-0002-8839-0562. \\ * E-mail of the corresponding author: halukyergin@yyu.edu.tr
}

\begin{abstract}
In this study, it is aimed to examine the relationship between energy imports and defense expenditures in the context of energy supply security for Turkey for the period 1990-2019. In the study, DF-GLS unit root test, BayerHanck (2012) cointegration test and Nazlioglu et al. (2016) Fourier Granger causality analysis and Enders and Jones (2016) Fourier Granger causality tests were used to examine the causal relationships between the variables. According to Nazlioglu et al. (2016) Fourier Granger causality analysis and Enders and Jones (2016) Fourier Granger causality analysis findings between variables, it was concluded that there is a one-way causality relationship from energy imports to defense expenditures.
\end{abstract}

Keywords: Energy Imports, Military Expenditures, Energy Supply Security, Time Series Analysis.

DOI: $10.7176 / \mathrm{JETP} / 12-1-03$

Publication date: February $28^{\text {th }} 2022$

\section{Introduction}

Energy and defence expenditures are important because they are among the subjects with economic and political dimensions. In the literature, energy security mostly comes to the fore in terms of security of supply, access of consumers to energy, and security of supply (Kirca et al., 2018: 157, 159). After the World War II, the energy need of the world economy is increasing with the effect of rapid growth, industrialization and population growth. With the 1973 Oil Crisis, the issue of energy security (energy supply security) is discussed. The IEA (International Energy Agency) was established in 1974 for the purpose of ensuring energy supply security at the international level (Canbay and Pirali, 2019: 400).

With the concept of energy supply security, which affects the economic and national security development of countries, it is expressed that countries meet their energy needs from uninterrupted, reliable, cheap, clean and diversified energy sources. It is also defined as the fact that the energy infrastructure of countries is not interrupted by terrorist attacks, supply interruptions due to investment declines, embargoes and strikes in all possible ways. With the concept of energy supply security, it is expressed that the possible changes in the access to existing energy resources and the insufficiency of energy resources as a result of the increase in energy demand (Caliskan, 2009: 306).

Energy security, that is, security of energy supply, is mostly explained in the literature with the concept of energy import, which expresses dependence on foreign energy. The notion of energy security changes depending on the energy policies implemented in the world, the types of energy used, the increasing energy demand of developing countries, the development of nuclear energy, the economic and political instability of the countries, and the liberalization of energy markets. The concept of energy supply security, on the other hand, depends on the energy supply and demand security as well as the changes in energy prices, wars, and the energy resources and energy infrastructure of the countries. According to the definition of IEA (2007), energy supply security depends on the lack of energy supply as well as the fluctuation of energy prices. Bohi and Toman (1996) explain the concept of energy security by dividing it into three groups with externalities. First, externalities associated with the amount of imports (intensity of energy imports), while the second includes the price of imported fuels (prosperity loss due to changes in energy prices and shortages in energy supply), third, it constitutes defence expenditures to maintain national security, which is used to maintain defence presence in areas where fuels are produced (Yildirim ve Karakoc, 2014: 440, 441). 
In this study, the relationship between foreign energy dependence (energy imports) and defence expenditures in the context of energy supply security for Turkey and 1990-2019 period, analyzed with DF-GLS unit root test, Bayer-Hanck (2012) cointegration test then applied Enders\&Jones (2016) Fourier Granger causality test, and Nazlioglu et al. (2016) Fourier Toda Yamamoto causality tests.

\section{The Relationship Between Energy Supply Security and Defence Expenditures}

Energy supply security is defined as "the realization of energy supply, transport and demand in sufficient quantity and quality, at reasonable cost/prices, uninterruptedly and in an environmentally friendly manner within the scope of energy production, transmission and consumption activities" (Stiller et al., 2008: 4195; Ediger, 2008: 62; Pamir, 2007: 14; Erdal and Karakaya: 2012: 115).

In order to ensure energy supply security, it is necessary to reduce the dependence on external sources in energy as much as possible, to take measures against the occurrence of disruptions such as a decrease, depletion, interruption, or shutdown that may occur from any source, and to diversify energy resources. It should be taken into account that the energy to be obtained from a single source or by using one source at a higher rate than the others will create a kind of dependency. One of the points to be considered in resource selection is to focus on the selection of resources that will not create dependency on a single country as well as on a single resource. It is also important not to be dependent on foreign countries and a single country not only in the resources to be selected, but also in the energy investments to be made (Ugurlu, 2007: 83).

Table 1: Energy Security Elements, Components and Potential Risks

\begin{tabular}{|c|c|c|}
\hline Items & Subcomponents & Potential Threats \\
\hline 㟒 & $\begin{array}{l}\text { 1- Having a physical resource. } \\
\text { 2- Ability of producer, transit country and } \\
\text { consumer countries to agree on energy } \\
\text { prices } \\
\text { 3- Development of technological solutions } \\
\text { for production, transportation, conversion, } \\
\text { storage and distribution. } \\
\text { 4- Capital investment } \\
\text { 5- Existence of applicable legal and } \\
\text { regulatory structures } \\
\text { 6- Compliance with environmental and } \\
\text { other regulatory requirements }\end{array}$ & $\begin{array}{l}\text { 1- Depletion of reserves } \\
\text { 2- Limitation of development opportunities } \\
\text { (nationalization and bilateral agreement) } \\
\text { 3- Infrastructure issues (for example, not in my } \\
\text { backyard understanding) } \\
\text { 4- Existence of financial, legal, regulatory and } \\
\text { political environments that do not allow } \\
\text { continuous investment }\end{array}$ \\
\hline 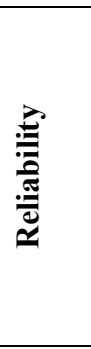 & $\begin{array}{l}\text { 1-Strong diversification of the entire } \\
\text { energy supply chain. } \\
\text { 2- Availability of sufficient reserves for the } \\
\text { entire energy supply chain } \\
\text { 3- Short and long term protection from } \\
\text { terrorist attacks, weather events and } \\
\text { political disruptions } \\
\text { 4- Having sufficient knowledge about the } \\
\text { functioning of the global energy market }\end{array}$ & $\begin{array}{l}\text { 1- The collapse of energy systems due to natural } \\
\text { events such as storms and earthquakes } \\
\text { 2- Problems due to insufficient maintenance or } \\
\text { underinvestment } \\
\text { 3- The threat of defence force or terrorist attack } \\
\text { 4- Political obstructions (such as embargo and } \\
\text { sanctions) }\end{array}$ \\
\hline 咅 & $\begin{array}{l}\text { 1- Low price volatility } \\
\text { 2- Transparent pricing } \\
\text { 3- Realistic expectations about future } \\
\text { prices: Financing is a problem related to } \\
\text { comparing current period and future energy } \\
\text { price expectations. } \\
\text { 4- Prices that increase in the short term and } \\
\text { are reflected in all costs as a problem that } \\
\text { exists in the long term. }\end{array}$ & $\begin{array}{l}\text { 1- Exhaustion of reasonable-cost reserves } \\
\text { 2-Increasing demand due to high energy intensity } \\
\text { and other incentive policies } \\
\text { 3-Not including the environmental dimension in } \\
\text { the scope of energy security }\end{array}$ \\
\hline
\end{tabular}




\begin{tabular}{|c|c|c|}
\hline 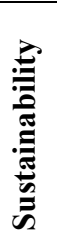 & $\begin{array}{l}\text { 1- Low emission of greenhouse gases and } \\
\text { other pollutants. } \\
\text { 2- Less contribution to local, regional or } \\
\text { global threats to environmental quality } \\
\text { 3- Protection of energy systems from the } \\
\text { effects of climate change. }\end{array}$ & $\begin{array}{l}\text { 1- Policy generation according to the narrow } \\
\text { definition of energy security } \\
\text { For example, increasing the use of coal before } \\
\text { filtration and storage technologies are developed. } \\
\text { 2- The effects of climate change (such as sea } \\
\text { level rise, severe weather events) }\end{array}$ \\
\hline
\end{tabular}

Source: Elkind, 2009: 122; Yildirim ve Karakoc, 2014: 441.

Based on the motto of Neal (1974), "but defense is more important than wealth", the concept of energy supply security is defined by Koyama and Kutani (2012) as "securing the amount of energy required for people's lives, economic, social and defense activities, together with other purposes, at a reasonable price level" (Peker, 2015: 766).

Figure 1. Dimensions of Energy Security

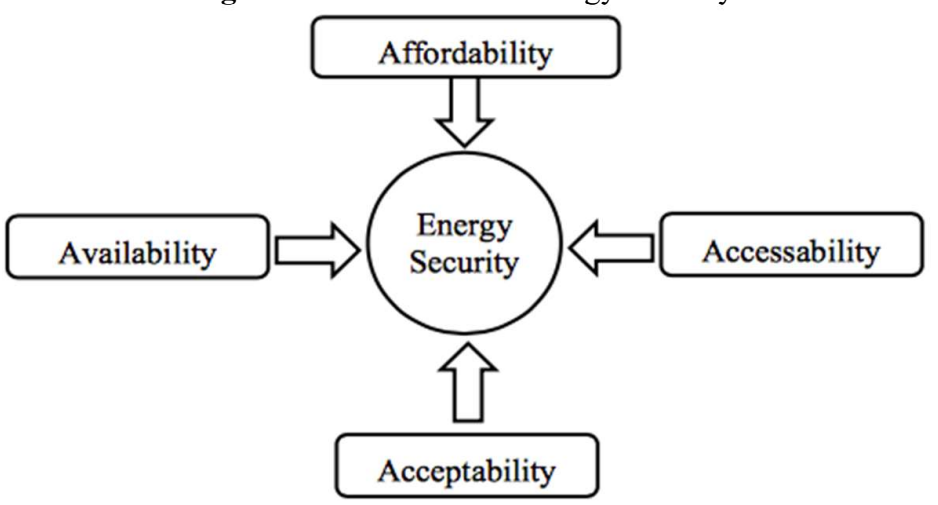

Source: Yilmaz 2021: 95.

Energy, components of supply security Kruyt et al. (2009), Jansen et al. (2004) and Elkind (2010), as factors that increase energy supply security, the availability of energy source (availability), being economical (affordability), accessibility and sustainability (Acceptability) also include the environmental dimension (as much as possible to the environment). it has the least negative effect) and is explained by its four main features. Factors affecting energy supply security mostly consist of economic, political and geographical factors (Erdal, 2011): An important method of increasing energy supply security is to reduce import dependency by supporting the use of alternative energy sources, which are less harmful to the economy and the environment, with new technologies. Although energy supply security is mostly examined with its economic dimension, it is also examined in terms of military, national security and political aspects along with the globalization process.

According to Balat (2010), energy supply security is the access to energy resources at a certain price level in a sufficient and reliable way for economic growth to be sustainable (Turkoglu, 2018: 12, 31). Ensuring energy supply security is possible by diversifying energy resources as well as by diversifying the regions where energy resources are provided (Sevim, 2012: 4386).

By reducing and reducing the difference between energy demand and energy supply, increasing energy efficiency and savings, it is aimed to diversify the energy supply sources by obtaining the optimum energy source composition. Thus, energy supply security will be ensured by investing in the development of energy infrastructure and transition to alternative and renewable energy sources and to ensure the sustainability of economic growth and it is aimed to provide sufficient and reliable energy supply at a reasonable price level (Balat, 2010: 1998).

Continuity of energy supply is important for these countries. Horsnell (2000) explains this situation with three different types of discontinuity as 'extraordinary interruption', 'export-restrictive interruption' and 'embargo interruption', as well as two different types of interruptions in energy supply, 'policy discontinuity' and 'basic discontinuity' (Yildirim and Karakoc, 2014: 442): Policy discontinuity is seen as a result of policy changes in producer countries due to insufficient production capacity. Fundamental discontinuity occurs when the energy supply cannot meet the national energy demand. The unusual interruption is explained by the decrease in the export of the producing country due to political instability and war. An export-restrictive interruption occurs when one or more producing countries decide to make significant restrictions on exports for political and strategic purposes. 
The embargo interruption is explained by the fact that the importing countries limit the exports of some of the producing countries.

Defense expenditures are made to ensure energy supply security of countries (Canbay and Pirali, 2019: 401). Especially in case of insufficient domestic energy resources, it creates pressure to increase energy imports. Therefore, these two components are closely related. Energy import is one of the most urgent problems in terms of national security. Energy security can be achieved by managing energy demand, increasing local energy supply, or increasing the security of imported and domestic energy supply suppliers. National and international security can be examined with three components: social, cultural and political, economic and military. Energy security issues interact with these three components (Deese, 1979: 140).

Defence spending is sometimes regarded as an externality as a cost of reducing energy security (Markandya and Hunt, 2004) rather than a cost of insecurity (Dahl, 1997: 131). Concerns about ensuring the security of energy supply chains are the domain of military logistics and security rather than economics (Metcalf, 2013: 25). For this reason, defence expenditures are made to prevent damage to total energy consumption (Ozdamar, 2010: 1419). For this purpose, it is argued that since the elimination and prevention of concrete threats to energy supply is possible with defence expenditures and defence expenditures should be included in the external cost of energy security (Markandya and Hunt, 2004).

\section{Literature Review}

Energy supply security and supply continuity are essential in almost all economic activities. Clark et al. (2010) argued that the military equipment and facilities of the armies of the countries, as well as the expenditures made to meet the personnel needs, cause an increase in energy consumption. The relationship between growth, defence expenditures and energy consumption is examined by the Bildirici (2017a) of G7 countries and the Bildirici (2017b) is examined for Brazil, Russia, India, China, Turkey, South Africa and Mexico there is a bidirectional causality relationship between energy consumption and defence expenditures (Canbay and Pirali, 2019: 401, 402). In addition, in the study of Canbay and Pirali (2019) is examined to Turkey, the $1 \%$ increase in defense expenditures increases energy imports by $0.27 \%$ in the long run.

\section{Econometric Analysis}

In this study, the period of 1990-2019 was examined in the context of the relationship between energy imports and defense expenditures for Turkey. In the study, the defense expenditures (Military expenditure \% of GDP) and energy imports, net ( $\%$ of energy use) an indicator of energy dependence, data were taken from the "data.worldbank.org" databases, and econometric analyzes of the study were carried out using the Eviews 10.0, Stata 12.0 and Gauss 10.0 econometric programs. In the study, DF-GLS unit root test and Bayer-Hanck (2012) cointegration test were applied, after Nazlioglu et al. (2016) Fourier Granger causality analysis and Enders and Jones (2016) Fourier Granger causality analysis were applied.

\section{1. DF-GLS Unit Root Test}

The DF-GLS unit root test developed by Elliott, Rothenberg and Stock (1996) gives better results in small samples compared to the standard Dickey-Fuller test when the series has an unknown mean and a linear trend. In the first stage of this test, which was developed in two stages, the generalized least squares method is used to calculate the constant and trend in the series. In the second stage of the test, the standard Dickey-Fuller test is applied to test the existence of an autoregressive unit root after the series is de-trended (Izolluoglu, 2019: 9). Based on the assumption that the error terms are independent and with constant variance, there should be heteroscedasticity (none constant variance) and autocorrelation in the error terms. Moreover, in the DF-GLS unit root test, the stationarity of the series is examined with the basic hypothesis of "the series contains a unit root". In case the calculated test statistic is greater than the critical value in absolute value, the basic hypothesis is rejected and the series are considered to be stationary (Yalcinkaya, 2019: 35, 37). In order to apply the DF-GLS (1996) test, the series must first be detrended. The data generation algorithm of the test is calculated according to equations 1 and 2 (Izolluoğlu, 2019: $15)$ :

$y_{t}=d_{t}+u_{t}$

$u_{t}=\alpha u_{t-1}+v_{t}$

In models, $d_{t}$ represents the deterministic component. $v_{t}$ has zero mean. Also it represents the error process with a positive spectral density function at stationary and zero frequency. If the main and alternative hypotheses are hypotheses,

$\mathrm{H}_{0}: \alpha=1$ (Series has unit root/series is first order integrated) 
$\mathrm{H}_{1}: \widetilde{\alpha}=|\alpha|<1$ (Series is not unit rooted/series is zero degree integrated)

Table 2. DF-GLS Unit Root Test

\begin{tabular}{|l|l|l|l|l|}
\hline \multirow{2}{*}{ Variables } & \multicolumn{2}{|c|}{ Constant } & \multicolumn{2}{c|}{ Constant+Trend } \\
\cline { 2 - 5 } & t-stat. & DF-GLS test stat. & t-stat. & DF-GLS test stat. \\
\hline Milex I(0) & -1.932 & -1.946 & -2.532 & -3.161 \\
\hline Milex I(1) & $-7.427 * *$ & -1.946 & $-8.098^{* *}$ & -3.164 \\
\hline Energy import I(0) & -1.297 & -1.946 & -1.783 & -3.174 \\
\hline Energy import I(1) & $-6.844 * *$ & -1.946 & $-7.080 * *$ & -3.177 \\
\hline
\end{tabular}

Note: $* * *, * *, *$ indicate $10 \%, 5 \%$ and $1 \%$ significance levels, respectively Milex: Defence Expenditures, Energy Import: Energy import.

When the DF-GLS unit root test findings are analyzed in Table 2, it is seen that the fixed and fixed+trend forms of the defense expenditures and energy imports variables for the Turkish economy are not stationary at the 5\% significance level (LV). It is understood that the absolute values of the critical values calculated for the variables in the DF-GLS unit root test are small, respectively. Also, it is seen that the series are stationary at the 5\% significance level at the first difference. It is decided by looking at whether the test statistical values for the variables are bigger than the critical table value at the 5\% significance level as an absolute value.

\begin{tabular}{|l|l|l|l|l|l|l|}
\hline Lag & LogL & LR & FPE & AIC & SC & HQ \\
\hline 0 & 234.40 & 5.3243 & 2.7335 & $9.6237^{*}$ & 8.0247 & 2.8615 \\
\hline 1 & 94.713 & 73.985 & $25.790^{*}$ & $11.835^{*}$ & $9.1646^{*}$ & $10.364^{*}$ \\
\hline 2 & 77.451 & 79.643 & 48.045 & 12.872 & 9.5612 & 10.511 \\
\hline
\end{tabular}

*: Appropriate lag-length

As can be seen from Table 3, before proceeding to the cointegration analysis, a decision is made according to the lag length by looking at the LR, FPE, AIC, SC and HQ information criteria. Therefore, the lag length is determined 1. In this direction, in the cointegration analysis, the analyzes are made by taking the variables in the first degree.

\subsection{Bayer-Hanck (2012) Cointegration Tests}

If the existing cointegration tests in the literature are evaluated briefly, the Engle-Granger cointegration test allows cointegration analysis between the series without considering the stationarity of the series, while the Johansen (1991) test is extremely sensitive to the lag length. While the Boswijk (1994) test is based on the error correction model and is compatible with the F statistic, Banerjee et al. (1998) test is a test based on error correction model and $t$ statistics. The difference of Bayer-Hanck (2012) cointegration test from other tests in the literature is that the results of the existing tests in the literature are contradictory, in Bayer and Hanck (2012) cointegration test EngleGranger (1987), Johansen (1991), Boswijk (1994) and Banerjee et al. (1998) it is possible to evaluate all of the cointegration tests. In Bayer-hanck (2012) cointegration test, Fisher chi-square distribution formula and EngleGranger (1987), Johansen (1991), Boswijk (1994) and Banerjee et al. (1998) test probability results are combined. From Equations 3 and 4, Engle-Granger (1987), Johansen (1991), Boswijk (1994) and Banerjee et al. (1998) cointegration test statistics values are greater than the critical value of Bayer-Hanck (2012), the basic hypothesis of Ho (zero hypothesis) which defines the existence of a cointegration relationship, is rejected. Therefore, it is concluded that there is a cointegration relationship between the series (Turhan, 2021: 70, 71):

$\mathrm{EG}-\mathrm{JOH}=-2\left[\ln \left(\mathrm{P}_{\mathrm{EG}}\right)+\ln \left(\mathrm{P}_{\mathrm{JOH}}\right)\right.$

$\mathrm{EG}-\mathrm{JOH}-\mathrm{BO}-\mathrm{BDM}=-2\left[\ln \left(\mathrm{P}_{\mathrm{EG}}\right)+\ln \left(\mathrm{P}_{\mathrm{JOH}}\right)+\ln \left(\mathrm{P}_{\mathrm{BO}}\right)+\ln \left(\mathrm{P}_{\mathrm{BDM}}\right)\right]$ 
Table 4: Bayer-Hanck (2012) Cointegration Tests Result

\begin{tabular}{|c|c|c|c|c|}
\hline \multicolumn{5}{|c|}{ Model 1: Milex = f(Energy import $)$} \\
\hline \multicolumn{5}{|c|}{ Fisher Type Test Statistics, Bayer Hanck Test } \\
\hline & Engle-Granger & Johansen & Banerjee & Boswijk \\
\hline p-values & 0.6250 & 0.7259 & 0.4333 & 0.5043 \\
\hline Test Statistics & -1.8033 & 5.7209 & -1.9657 & 4.3655 \\
\hline \multicolumn{5}{|c|}{$\begin{array}{l}\text { EG-J: } 15.8069 \\
10 \% \text { critical value: } 8.678\end{array}$} \\
\hline \multicolumn{5}{|c|}{$\begin{array}{l}\text { EG-J-Ba-Bo: } 46.2251 \\
10 \% \text { critical value: } 16.964\end{array}$} \\
\hline \multicolumn{5}{|c|}{ Model 2: Energy import $=$ f(Milex $)$} \\
\hline & Engle-Granger & Johansen & Banerjee & Boswijk \\
\hline p-values & 0.7418 & 0.7259 & 0.9009 & 0.9716 \\
\hline Test Statistics & -1.5448 & 5.7209 & -0.6228 & 0.4263 \\
\hline \multicolumn{5}{|c|}{ Fisher Type Test Statistics, Bayer Hanck Test } \\
\hline \multicolumn{5}{|c|}{$\begin{array}{l}\text { EG-J: } 12.3803 \\
10 \% \text { ciritical value: } 8.678\end{array}$} \\
\hline \multicolumn{5}{|c|}{$\begin{array}{l}\text { EG-J-Ba-Bo : } 18.0435 \\
10 \% \text { ciritical value: } 16.964\end{array}$} \\
\hline
\end{tabular}

In line with the Bayer-Hanck (2012) cointegration test findings expressed in Table 4, each variable was taken as a dependent variable, respectively, and if the test statistical value obtained in both models was bigger than $10 \%$ critical value, the basic hypothesis was rejected, the alternative hypothesis was accepted and both models. According to the results, it is decided that there is a cointegration relationship between the series in the long run.

4. 3. Nazlioglu et. al. (2016) Fourier Toda-Yamamoto Causality Test

Nazlioglu et al. (2016), the causality test VAR model, which was brought to the literature by structural changes, is included and the VAR $(\mathrm{p}+\mathrm{d})$ model is estimated. The lag length is defined in the model with ' $\mathrm{p}$ ' and the maximum degree of cointegration of the variables 'd'. Nazlioglu et al. (2016) test is a test based on Granger causality approach developed by Toda and Yamamoto (1995). In the Toda Yamamoto causality analysis approach, wave breaks are modeled with the Fourier method and analyzed. The model of the test is expressed in Equation 5 (Konat, 2021: 909):

$\mathrm{y}_{\mathrm{t}}=\alpha_{0}(\mathrm{t})+\beta_{1} \mathrm{y}_{\mathrm{t}-1}+\cdots+\beta_{\mathrm{p}}+d y_{t}-(\mathrm{p}+\mathrm{d})+\varepsilon_{\mathrm{t}}$

The constant term parameter $\alpha_{0}(t)$ expressed in Equation 5 is included in the model in order to capture the structural changes in the dependent variable depending on time, and equation 6 is obtained (Çağlar and Kubar, 2017: 109; Konat, 2021: 909):

$$
\gamma_{t}=\alpha_{0}+\gamma_{1 k} \sin \left(\frac{2 \pi k t}{T}\right)+\gamma_{2 k} \cos \left(\frac{2 \pi k t}{T}\right)+\beta_{1} y_{t-1}+\cdots+\beta_{p+d} y_{t}-(p+d)+\varepsilon_{t}
$$

In Equation 6, while ' $k$ ' refers to the frequency number, $\gamma_{1 k}$ ve $\gamma_{2 k}$ define the frequency width. Structural breaks can be captured with sine and cosine waves by not knowing the breaking time and number of added Fourier terms. Nazlioglu et al. (2016) suggested the use of F test statistic instead of Wald test statistic, since the $\chi^{2}$ distribution is insufficient due to its inability to examine small samples in causality tests, and by determining the frequency value of the appropriate lag and Fourier terms, the hypothesis that the main hypothesis of the test is that there is no causality is tested (Konat, 2021: 909). 
Table 5. Nazlioğlu et. al. (2016) Fourier Toda-Yamamoto Causality Test

\begin{tabular}{|l|l|l|l|l|l|}
\hline Causality Direction & F-stat & Asimptotik p-value & Bootstrap p-value & $\mathrm{p}$ & $\mathrm{k}$ \\
\hline Ener to Defence & 4.859 & 0.028 & $0.028^{* *}$ & 2 & 3 \\
\hline Defence to Ener & 0.258 & 0.611 & 0.591 & 2 & 3 \\
\hline Note: Optimal lag lenght and Fourier frequency lengths were determined by AIC with a maximum of 3. \\
$\begin{array}{l}\text { Bootstrap repetition count is 1000. ***, ** and * indicate 1\%, 5\% and 10\% statistical significance levels, } \\
\text { respectively. Ener: Energy import, Defence: Defense Expenditures. }\end{array}$
\end{tabular}

In Table 5, the results of Fourier Toda-Yamamoto causality analysis, which is a test in which structural breaks are taken into account, are given. In line with the analysis findings, it is seen that there is a one-way causality relationship between energy imports and defense expenditures from energy imports to defense expenditures.

\section{4. Enders and Jones (2016) Fourier Granger Causality Test}

Contrary to the VAR (vector autoregressive model) model, which does not take into account the structural breaks, the Enders and Jones (2016) test uses the flexible Fourier function to examine the breaks in the VAR system with Fourier-Granger causality analysis. Granger causality tests are applied using Fourier terms to control the breaks. It is stated that the results obtained by adding trigonometric functions to VAR with the Enders and Jones (2016) test give different and stronger results for the causal relationship (K1lc1, 2019: 225). Instead of the VAR equation of Enders and Jones (2016), the model of the test is defined as expressed in equation 4 (Pata and Ela, 2020: 181, 182):

$y_{t}=\beta_{0}+\gamma_{1 k} \sin \left(\frac{2 \pi k t}{T}\right)+\gamma_{2 k} \cos \left(\frac{2 \pi k t}{T}\right)+\vartheta_{1} y_{t-1}+\cdots+\vartheta_{u} y_{t-u}$

In this study, causality analysis was performed using the single-frequency Fourier-Granger causality test, since the number of observations was few. If the null hypothesis of the test, which is expressed as "there is no causal relationship between the variables", is rejected, it is decided that there is a causal relationship with the structural changes.

Table 6. Enders and Jones (2016) Fourier Granger Causality Test

\begin{tabular}{|l|l|l|l|l|l|}
\hline $\mathrm{H}_{0}$ hypothesis & Wald Stat. & Asymptotic p-value & Bootstrap p-value & $\mathrm{p}$ & $\mathrm{k}$ \\
\hline Ener to Defence & 3.665 & 0.056 & $0.057 * *$ & 2 & 3 \\
\hline Defence to Ener & 1.209 & 0.272 & 0.281 & 2 & 3 \\
\hline $\begin{array}{l}\text { Note: Optimal lag lenght and Fourier frequency lengths were determined by AIC with a maximum of } 3 . \\
\text { Bootstrap repetition count is 1000. ***, ** and * indicate 1\%, 5\% and 10\% statistical significance levels, } \\
\text { respectively. Ener: Energy import, Defense: Defense Expenditures. }\end{array}$
\end{tabular}

The causality relationship between energy imports and defense expenditures variables is expressed in tables 5 and 6 by Nazlıoglu et al. (2016) and Enders and Jones (2016) were examined by Fourier Granger causality analyzes that take into account the structural breaks. The findings of the causality analyzes indicated that there was a oneway causality relationship from energy imports to defense expenditures at the $5 \%$ significance level in both causality tests.

\section{CONCLUSION}

Foreign dependency in energy is also defined by how much energy is imported. Energy dependence has not only an economic aspect, but also a political aspect. Since a significant share of the energy needs of a country that is dependent on foreign energy is met by external resources, this situation also leads to a weakness in national security. The issue of energy dependency is also an important issue of energy supply security. Security of supply in energy is a problem that mostly covers foreign-dependent countries in terms of energy. Energy dependence increases foreign dependency in terms of imports. The foremost method to ensure energy supply security for energy importing countries is to ensure energy supply diversity. Social, cultural and political, economic and military components are components of energy supply security. The first of the two basic economic and political components of energy security is the first factor that affects the quantity and reliability of domestic energy resources. The second affects external (imported) energy sources.

In this study, which examines Turkey for the period 1990-2019, the relationship between energy imports and defense expenditures in the context of energy supply security has been examined. DF-GLS unit root test, BayerHanck (2012) cointegration test and causality relationship between variables Nazlioglu et al. (2016) Fourier Granger causality analysis and Enders and Jones (2016) Fourier Granger causality tests. In line with the Nazlioglu et al. (2016) Fourier Granger causality analysis found a one-way causality relationship between the variables from energy imports to defense expenditures. 
Although energy expenditures are not considered among the traditional production factors, it is defined as one of the production factors in the modern production style. Defense expenditures also require a significant amount of energy. Countries in terms of energy use, those who meet their energy needs with significant imports, those who can produce energy to meet their own needs, and those who export energy are handled in three groups. Turkey is in the third group among these, that is, it is among the countries that are highly dependent on foreign energy in terms of energy. A portion of energy imports is used to meet the needs of defense expenditures. In this respect, there is a causality between energy imports and defense expenditures.

\section{REFERENCES}

Balat, M. (2010), "Security of Energy Supply in Turkey: Challanges in and Solutions", Energy Conversion and Management., 51 (10), 1998-2011.

Banerjee, A. vd. (1998), "Error-correction Mechanism Tests for Cointegration in a Single-equation Framework", Journal of Time Series Analysis, 19(3), 267-283.

Bayer, C., \& Hanck, C. (2013), “Combining Non-Cointegration Tests”, Journal of Time Series Analysis, 34 (1), 83-95.

Bildirici, M. (2017a). CO2 Emissions and Militarization in G7 Countries: Panel Cointegration and Trivariate Causality Approaches. Environment and Development Economics, 22 (6), 771-91.

Bildirici, M. (2017b), "Militarization, Economic Growth and Petroleum Consumption in Brazil, Russia, India, China, Turkey, South Africa and Mexico", Economic Computation and Economic Cybernetics Studies and Research, 51(2), 249-66.

Clark, B., Jorgenson, A., K. \& Kentor, J. (2010), “Militarization and Energy Consumption”, International Journal of Sociology, 40 (2), 23-43.

Bohi D., R., Toman M., A. (1996), "Empirical Evidence on Energy Security Externalities. In: The Economics of Energy Security”, Springer, 31-58.

Boswijk, H.P. (1994), "Testing for an Unstable Root in Conditional and Structural Error Correction Models", Journal of Econometrics, 63(1), 37-60.

Canbay, S. \& Pirali, K. (2019), "The Effects of Defense Expenditures and Renewable Energy Consumption on Energy Imports in Turkey”, Journal of Academic Research and Studies (AKAD), 11(21), 398-410.

Caliskan, S. (2015), “Turkey's Foreign Dependency in Energy and Energy Supply Security Problem”, Dumlupınar University Journal of Social Sciences, 25, 297-310.

Dahl, C. (1997), “The Economics of Energy Security. The Energy Journal”, 18(1), 129-131, "https://www.jstor.org/stable/pdf/41322723.pdf", Date of Access: 10.05.2021.

Deese, D. A. (1979), "Energy: Economics, politics, and security”, International Security. 4(3), 140-153.

Ediger, V. S. (2008), "Interdependence is a Necessity in Energy Security of the New Century", Journal of Natural Gas, 132, 59-62.

Elkind, J. (2010), "Call for a broader agenda”, In C. Pascual, J. Elkind (Eds.), Energy security: Economics, politics, strategies and implications (pp. 119-148). Washington D. C.: Brookings Institutation Press.

Enders, W. \& Jones, P. (2016). Grain Prices, Oil Prices, and Multiple Smooth Breaks in a VAR. Studies in Nonlinear Dynamics \& Econometrics, 20 (4), 399-419.

Elliott, G., Rothenberg, T., J. \& Stock, J., H. (1996), "Efficient tests for an autoregressive unit root", Econometrica, 64, 813-836.

Engle, R.F. \& C.W Granger (1987), “Co-integration and Error Correction: Representation, Estimation, and Testing”, Econometrica: Journal of the Econometric Society, 251-276.

Erdal, L. (2011), "Factors Affecting Energy Supply Security and Renewable Energy Sources Alternative", PhD Thesis, Adnan Menderes University, Institute of Social Sciences, Aydin.

Erdal, L., \& Karakaya, E. (2012), "Economic, Political and Geographical Factors Affecting Energy Supply Security", Uludag Journal of Economy and Society, 31(1), 107-136.

Gilbert E. \& Metcalf, (2014), “The Economics of Energy Security”, Annual Reviews, 6 (1), 155-174.

Horsnell, P. (2000), "Japanese energy security and changing global energy market: an analysis of Northeast Asian energy cooperation and Japan's evolving leadership role in the region”, Rice University.

IEA. (2007), "Energy security and climate change; assessing interactions", International Energy Agency, Paris, "https://www.iea.org/reports/energy-security-and-climate-policy". Date of access (20.08.2021).

Izolluoglu, C. (2019), “Time Series Unit Root Tests and an Application”, Master Thesis, Inonu University, Institute of Social Sciences, Malatya.

Jansen, J., van Arkel, W. \& Boots, M. (2004), “Designing indicators of long-term energy supply security”, ECNC-04-007, January 2004, The Energy research Centre of Netherlands. 
Johansen, S. (1988), "Statistical Analysis of Cointegration Vectors", Journal of Economic Dynamics and Control, 12(2-3), 231-254.

Kirca, M. et al. (2018), "Economic And Political Analysis of Interaction of the Relationships Between Energy Imports and Military Spending In Turkey”, ENSCON'18 - International Congress of Energy, Economy and Security, 155-169.

Konat, G. (2021), "Public Expenditure and Foreign Trade Relationship in Turkey: Fourier Causality Approach", International Journal of Management Economics and Business, 17(3), 900-917.

Koyama, K. \& Kutani, I. (2012), "Study on the Development of an Energy Security Index and an Assessment of Energy Security for East Asian Countries", ERIA Research Project Report 2011, No. 13.

Kruyt, B., Van Vuuren, D. P., De Vires, H. J. M. \& Groenenberg, H. (2009), "Indicators for energy security", Energy Policy, 37(6), 2166-2181.

Markandya, A. \& Hunt, A. (2004), “The externalities of energy insecurity”, ExternE-Pol research project for the European Commission.

Nazlioglu, S., Gormus A. \& Soytas, U. (2016), “Oil Prices and Real Estate Investment Trusts (REITs): GradualShift Causality and Volatility Transmission Analysis”, Energy Economics. 1-28.

Neal Larry \& Adam Smith (1974), "Defence and Opulence”, Faculty Working Papers, College of Commerce and Business Administrataion University of Illinois at Urbans - Champaign.

Ozdamar, O. (2010), "Energy, Security, and Foreign Policy", The International Studies Encyclopedia, Edit: Denemark, R., A., Marlin-Bennett, R., Wiley-Blackwell Publication, 1415-1433.

Pamir, N. (2007), "Energy Supply Security and Turkey", ASAM, Strategic Analysis. March, 14-24.

Pata, U., K., \& Ela, M. (2020), "Effects of Financial Development on Tax Revenues in Turkey: Fourier Cointegration and Causality Tests", ISMMMO Journal of Financial Solutions, 30(158), 171-188.

Peker, H., S. (2015), “Turkey's Energy Supply Security and Measurement: An Application for Turkey's Energy Supply Security Index", Journal of Cankiri Karatekin University Faculty of Economics and Administrative Sciences, 5(2), 763-783.

Sevim, C. (2012), “Global Energy Geopolitics and Energy Security”, Yaşar University E-Journal, 7(26), 43784391.

Stiller, C., Seydel, P., Bunger, U. \& Wietschel, M. (2008), "Early Hydrogen User Centres and Corridors as Part of The European Hydrogen Energy Roadmap (Hyways)”, International Journal of Hydrogen Energy, 33(41), 4193-4208.

Turhan, G., T. (2021), “The Relationship between Financial Openness and Growth in Turkey: Bayer-Hanck (2013) Cointegration Analysis", International Journal of Applied Economic and Finance Studies 6(1), 65-75.

Turkoglu, S. (2018), "Energy Consumption - Current Account Deficit - Exchange Rate Relationship: An Analysis on OECD Countries", Master Thesis, Hasan Kalyoncu University Institute of Social Sciences, Gaziantep.

Ugurlu, O. (2007), "Redefining Turkey's Energy Security”, TMMOB Chamber of Environmental Engineers, 7th National Environmental Engineering Congress, Life Environment Technology, 24-27 October, Izmir, 8192.

Yalcinkaya, O. (2019), "Analysis of the Sustainability of External Debt in the Turkish Economy: Evidence from Linear and Nonlinear Unit Root Tests (1970-2018)", Journal of Finance, 176, 27-51.

Yildirim, E. \& N. Karakoc (2014), "Energy Supply Security in Black Sea Countries”, I. Black Sea and Balkan Economic and Political Studies Symposium, 438-453.

Yilmaz, A. (2021), "Energy Supply Security Index: An Analysis for Turkish Economy”, Suleyman Demirel University Journal of Vizyoner, 12(29), 92-117. 